\title{
Review: Converting nutritional knowledge into feeding practices: a case study comparing different protein feeding systems for dairy cows
}

\author{
H. Lapierre ${ }^{1 \dagger}$, M. Larsen ${ }^{2}$, D. Sauvant ${ }^{3}$, M. E. Van Amburgh ${ }^{4}$ and G. Van Duinkerken ${ }^{5}$ \\ ${ }^{1}$ Agriculture and Agri-Food Canada, Sherbrooke, QC, Canada JOB 1M0; ${ }^{2}$ Department of Animal Science, Aarhus University, DK-8830 Tjele, Denmark; \\ ${ }^{3}$ INRA, AgroParisTech, Université Paris-Saclay, 75005 Paris, France; ${ }^{4}$ Department of Animal Science, Cornell University, Ithaca, NY 14850, USA; \\ ${ }^{5}$ Wageningen University \& Research, Wageningen Livestock Research, 6708WD Wageningen, The Netherlands
}

(Received 16 January 2018; Accepted 22 May 2018; First published online 24 August 2018)

\begin{abstract}
Improving milk nitrogen efficiency through a reduction of $\mathrm{CP}$ supply without detrimental effect on productivity requires usage of feeding systems estimating both the flows of digestible protein, the exported true proteins and from these predict milk protein yield (MPY). Five feeding systems were compared in their ability to predict MPY v. observed MPY in two studies where either protein supply or protein and energy supply were changed. The five feedings systems were: Cornell Net Carbohydrate and Protein System (v6.5.5), Dutch protein evaluation system (1991 and 2007), Institut National de la Recherche Agronomique in France (INRA), National Research Council and NorFor. The key characteristic of the systems with the best predicted MPY was the inclusion of a variable efficiency of utilisation of protein supply taking into account the supply of both protein and energy. The systems still using a fixed efficiency had the highest slope bias in their prediction of MPY. Therefore, the development of new feeding systems or improvement of existing systems should include a variable efficiency of utilisation of the protein related to both the protein and energy supply. The limitation of the current comparison did not allow determining if additional factors, as used in INRA, were beneficial. This concept should also probably be transferred to essential amino acids.
\end{abstract}

Keywords: dairy cows, feeding system, protein, energy, milk protein yield

\section{Implication}

Improving dairy farm profitability while decreasing total nitrogen losses can be reached through a reduced input of dietary protein, provided productivity is not compromised. To correctly predict milk protein yield (MPY) when protein and/or energy supply vary, the feeding systems used to balance dairy rations must assign a variable efficiency to the use of digested protein to support the different protein functions. An adequate prediction of MPY will allow a reduction of the protein in dairy rations, which has the dual effect of decreasing feed cost and increasing the farm net income while reducing nitrogen excretion into the environment.

\section{Introduction}

To the continued challenge of making dairy farming more cost effective, is now added the pressure to reduce environmental pollution from nitrogen $(\mathrm{N})$ derived from animal

\footnotetext{
${ }^{\dagger}$ E-mail: Helene.Lapierre@agr.gc.ca
}

waste. The efficiency of utilisation of $\mathrm{N}$ is often pointed out as being very low in dairy cows. Indeed, milk $\mathrm{N}$ efficiency (milk-N/N intake) has been reported to average, for example, 0.247 in 736 North American diets and 0.277 in 998 North European diets, but with a wide range from 0.140 to 0.453 (Huhtanen and Hristov, 2009). Obviously, all ingested N not secreted into milk or included in whole body protein accretion is excreted in faeces or in urine. The environment has become an increased societal issue and thus leading to increased concern about the impact of animal production on $\mathrm{N}$ emissions. It has to be remembered, however, that if, in the calculation of $\mathrm{N}$ efficiency, the ruminant $\mathrm{N}$ intake would only include human-edible protein sources, the ratio would be higher than 1 for dairy cattle, ranging from 1.4 to infinite, the latter if the animal consumes no human edible food (Dijkstra et al., 2013a).

Improving dairy farm profitability while decreasing total $\mathrm{N}$ losses can be reached through a reduced input of dietary CP, provided productivity is not compromised. The theoretical highest threshold of milk $\mathrm{N}$ efficiency in a dairy cow producing $40 \mathrm{~kg} / \mathrm{day}$ of fat- and protein-corrected milk has been 
evaluated to be 0.43 (Dijkstra et al., 2013b). These authors concluded that reduction of $\mathrm{N}$ losses through changes in microbial nucleic acid synthesis, $\mathrm{N}$ recycling to the rumen, digestibility of microbial protein or maintenance requirements were unlikely to happen. However, they suggested that focussing on optimal supply of rumen-degradable protein and optimising the efficiency of utilisation of absorbed amino acids (AA) would be potential strategies for reducing $\mathrm{N}$ losses and improving $\mathrm{N}$ efficiency. Therefore, improving milk $\mathrm{N}$ efficiency through a reduction of $\mathrm{CP}$ supply without detrimental effect on productivity requires usage of feeding systems specifically designed to estimate on one hand, the flows of digestible protein (DiP) and individual $A A$, and on the other, the requirements of true protein and $A A$, and from these predict MPY from a given diet for a certain type of cows. The ultimate objective of feed evaluation systems is providing dairy farmers with a tool that enables cost effective allocation of feed ingredients to supply nutrients to support the targeted production level. The accuracy and precision of the estimation of both the supply and the requirements are therefore critical to achieve this goal.

In Europe and North America, since 2010, there were several re-evaluations of existing feeding systems: for example, updates were proposed for the Cornell Net Carbohydrate and Protein System (CNCPS) in the United States (Fox et al., 2004; Van Amburgh et al., 2015), for the DVE/OEB system in the Netherlands (Tamminga et al., 1994; Van Duinkerken et al., 2011), for the Institut National de la Recherche Agronomique in France (INRA) (2018) and NorFor was developed in Scandinavia (NorFor, 2011). Therefore, the objectives of the current paper were (1) to compare qualitatively the basis of the requirements of DiP for nonproductive functions and milk protein; (2) to compare the predicted MPY responses to dietary changes involving variations in DiP and/or energy supply between these four feeding systems and the National Research Council (NRC) (2001); and (3) determine, if possible, why certain systems would yield better predictions. The NRC (2001) was kept as a reference of pre-2010 models and although it is currently under revision, the latest revision could not be included in the current comparison. Note that the current comparison was limited to only two studies: one involving variation of protein supply and one including variation in protein and/or energy supply. As mentioned previously, the final objective was to determine which factor(s) should be kept or integrated in feeding systems to improve predictions of MPY and not to make a thorough comparison of the feeding systems.

\section{Evolution of the feeding systems}

\section{Cornell Net Carbohydrate and Protein System}

The CNCPS feeding system was first published in 1992 and 1993 (Fox et al., 1992; Russell et al., 1992; Sniffen et al., 1992; O'Connor et al., 1993) with the principal objective of serving as a tool for both research development and feed formulation for cattle. Over time, the CNCPS has been evolving by incorporation of new research data and descriptions of rumen function and metabolism with the primary objective of field application and diet formulation. As a consequence, several updated versions have been released (e.g. Fox et al., 2004; Tylutki et al., 2008), with the last version as CNCPS 6.5 (Van Amburgh et al., 2015). The version 6.5.5 was used to calculate the estimations presented in the current paper. The DiP requirement and supply are referred to as metabolisable protein in CNCPS.

\section{DVE/OEB system}

In the Netherlands, the DVE/OEB (DVE $=$ DarmVerteerbaar Eiwit (ileal digestible protein)/OEB $=$ Onbestendig Eiwit Balans (rumen-degradable protein balance)] system for protein evaluation in ruminants, introduced by Centraal Veevoederbureau (CVB) in 1991 (Tamminga et al., 1994), is referred to as DVE-1991 in the current study. An update, to renew the concepts and assumptions related to the representation of chemical components in feed materials, the rumen-degradation characteristics of these components, the efficiency of microbial protein synthesis and the fractional passage rates of various components, has been described (Tamminga et al., 2007) and the basic concepts have been disclosed to the international scientific community by Van Duinkerken et al. (2011): it is referred to as DVE-2007. However, based on the results of two feeding experiments with lactating dairy cows, the DVE-1991 system performed better than the DVE-2007 system in predicting the MPY for cows on different diets (Van Duinkerken, 2011). For this and other reasons, the DVE-2007 system still has the status of a preliminary system in the Dutch feeding tables of CVB (2016), and the DVE-1991 system is still listed in these tables. Therefore, in the current study, we have included both versions of the DVE/OEB system in our evaluation. The DiP requirement and supply are referred to as DVE in the DVE/OEB systems.

\section{Institut National de la Recherche Agronomique}

Since 1978, INRA has regularly updated the French Feed Unit Systems. The INRA (2018) is the last update following INRA (2007). Because the latter, as many older systems, rather poorly integrates protein $\times$ energy interactions and phenomena of digestive interactions, it was found not to accurately apply to extreme diets, such as low $\mathrm{N}$ or high cell-wall diets or to very high-energy density diets ingested at high feeding levels. The objective of INRA (2018) was to entirely renew the calculation of the energy and protein feed and diets values, taking into account the main digestive phenomena (digestive interactions, passage rates, microbial synthesis, protein $\times$ energy interactions and rumen protein balance; Sauvant and Nozière, 2016). Moreover, as part of the revision, the protein requirements as well as responses to changes in protein supply were almost entirely updated using meta-analyses of large databases obtained from literature (Sauvant et al., 2015). The calculation of the response applied in the current work was published by Daniel et al. (2016 and 2017) and will be referred to as INRA (2018). The 
DiP requirement and supply are referred to as protein digestible in the intestine in INRA (2018).

\section{NorFor}

NorFor, the Nordic feed evaluation system (NorFor, 2011), was initiated in 2003 as a common project by the farmers dairy cooperatives in Denmark, Iceland, Norway and Sweden to create a common feed evaluation. This was taken as an opportunity to develop a completely new framework for the feed evaluation system based on current, published knowledge to replace the previous additive systems. The NorFor system uses a semi-mechanistic approach to calculate the nutrient supply to the animal. The nutrient requirements are calculated using a factorial approach. The system was introduced for practical use in 2006 and officially published in 2011 (NorFor, 2011). Since 2011, several updates have been released and these can be assessed at the NorFor homepage (www.norfor.info). Updates of particular relevance to this comparison are a reparameterised equation of the AA efficiency, revised curves for mobilisation and deposition during lactation, and a revised starch digestion submodel affecting the rumen microbial synthesis. Thus, equations used and given in tables of the current publication may differ from the NorFor book (NorFor, 2011). The DiP requirement and supply are referred to as $\mathrm{AAT}_{\mathrm{N}}$ in NorFor.

\section{National Research Council}

Since 1944, the NRC has published seven editions of Nutrient Requirements of Dairy Cattle: NRC (2001) is the 7th revised edition and will be referred to as NRC (2001). The primary differences between the protein system of the last and that from the previous edition related mainly to predicting DiP supply. The NRC (2001) introduced the DiP (metabolisable protein) concept, which was based on the division of feed CP into at least three biologically distinct fractions or pools, a feed library of in situ generated $\mathrm{N}$ fraction data to calculate rumen-degraded protein and rumen-undegraded protein proportion of a feed, not considered constant anymore, but affected by competing rates of ruminal degradation and passage. Estimates of intestinal digestibility have been assigned to the rumen-undegraded protein fraction of each feed ingredient. Endogenous protein has also been recognised to contribute to passage of $\mathrm{CP}$ to the small intestine. The DiP requirement and supply are referred to as metabolisable protein in NRC (2001).

\section{Amino acids}

All feeding systems predict the digestible flows of all essential amino acid (EAA) except Trp for NRC (2001) and only for Lys and Met for DVE/OEB feeding systems.

\section{Predictions of milk protein yield}

\section{Exported true proteins}

Over the years, feeding systems have greatly focussed on rumen sub-models to refine estimates of duodenal protein flow, which are reasonably accurate (Pacheco et al., 2012). Hence, special attention will be devoted in this paper on the estimation of requirements. The term 'exported true proteins' refer to the often called net protein requirement. It includes, in the current comparison, true proteins exported out of the cow and on a more general basis would also include whole body protein accretion or loss. An efficiency factor is assigned to each of these exports; ideally, they should be expressed as true protein because once divided by the efficiency, it generates the DiP requirement, which represents true protein. It is not, however, the case in all systems. The equations used in each system to estimate the exported proteins for non-productive functions, which divided by the efficiency of utilisation of DiP yields the protein requirement, are detailed in Table 1. True milk protein production is consistently used to estimate the exported true protein for milk protein. To simplify the comparison between the systems, changes in BW and gestation are not included.

To allow a quick comparison between the systems for the estimations of the exported proteins, a comparison has been made for the average cow of Study 1 (Olmos Colmenero and

Table 1 Equations used to estimate the export proteins (g/day) for non-productive functions by different protein feeding systems for dairy cows

\begin{tabular}{|c|c|c|c|c|}
\hline \multirow[b]{2}{*}{$\begin{array}{l}\text { Feeding } \\
\text { system }^{1}\end{array}$} & \multicolumn{4}{|c|}{ Non-productive function } \\
\hline & Scurf ${ }^{2}$ & $\begin{array}{l}\text { Endogenous } \\
\text { urinary }^{2}\end{array}$ & Metabolic faecal ${ }^{3}$ & Endogenous duodenal ${ }^{3}$ \\
\hline CNCPS & $0.2 \times B W^{0.6}$ & $2.75 \times \mathrm{BW}^{0.5}$ & $90 \times$ undigested $\mathrm{DM}_{\mathrm{kg}}$ & - \\
\hline DVE & $0.2 \times B W^{0.6}$ & $2.75 \times \mathrm{BW}^{0.5}$ & $50 \times$ undigested $\mathrm{DM}_{\mathrm{kg}}^{4}$ & - \\
\hline INRA (2018) & $0.2 \times \mathrm{BW}^{0.6}$ & $0.05 \times 6.25 \times B W$ & $\mathrm{DMI}_{\mathrm{kg}} \times\left[0.5 \times\left(5.7+0.074 \times\right.\right.$ undigested $\left.0 \mathrm{M}_{\mathrm{g} / \mathrm{kgDM}}\right)$ & - \\
\hline NorFor & $0.2 \times B W^{0.6}$ & $2.75 \times \mathrm{BW}^{0.5}$ & $\begin{array}{l}\left.\text { (rumen outflow } \mathrm{OM}_{\mathrm{g} / \mathrm{day}} \times 0.03 \times 0.5 \times 3 \times 0.4\right)+(\text { small intestinal outflow } \\
\left.\mathrm{OM}_{\mathrm{g} / \text { day }} \times 0.025 \times 0.5\right)\end{array}$ & - \\
\hline NRC (2001) & $0.2 \times \mathrm{BW}^{0.6}$ & $2.75 \times \mathrm{BW}^{0.5}$ & {$\left[\left(\mathrm{DMI}_{\mathrm{kg}} \times 30\right)-\left[0.50 \times\left(\left(\right.\right.\right.\right.$ bacterial $\left.\mathrm{DiP}_{\mathrm{g} / \text { day }} / 0.80\right)-$ bacterial $\left.\left.\mathrm{DiP}_{\mathrm{g} / \text { day }}\right)\right]$} & $\left(1.9 \times 6.25 \times \mathrm{DMI}_{\mathrm{kg}}\right) \times 0.4$ \\
\hline
\end{tabular}


Broderick, 2006), producing $38.3 \mathrm{~kg} /$ day of milk at $3.09 \%$ true protein, $3.27 \%$ fat and consuming $23 \mathrm{~kg} / \mathrm{day}$ of dry matter (DM) of the $16.5 \%$ CP diet detailed in the next section. The cow is at 120 days in milk, not pregnant and not changing its BW $(589 \mathrm{~kg})$, thus assuming energy and protein neutral except for the export proteins. The results of the comparison are detailed in Table 2. The NorFor model displays the lowest total exported proteins, whereas NRC (2001) model has the highest. Whereas the other systems are using the 'historical' estimation of endogenous-urinary $\mathrm{N}$ excretion from Swanson (1977), INRA (2018) has revisited this requirement. The intercept of the relationship between urinary $\mathrm{N}$ corrected for purine derivatives from microbial origin and digestible $\mathrm{N}$ intake in studies where faecal $\mathrm{N}$ was equal to N intake (Sauvant et al., 2015) was defined as the endogenous urinary $\mathrm{N}$ excretion and yielded an estimation higher than what was previously used. Therefore, INRA (2018) is the only system with a high estimation of the endogenous urinary excretion. The NRC (2001) is the only system to include a DiP requirement for the endogenous protein flowing at the duodenum, but also includes it as a supply. In the DVE/OEB system, the metabolic faecal is not included in the requirement, as it is considered to be a consequence of the diet and not related to the dairy cow. However, for comparison purposes, it was added in the current estimation. To be really significant, however, all these exported proteins need to be associated with the corresponding estimated supply: they will demonstrate their relevance when used together to predict MPY.

\section{Supply of digested proteins}

The supply of digested proteins is estimated differently in each system, but presents some commonalty. First, the duodenal flow of CP is estimated as the sum of undegraded dietary proteins and protein from rumen microbial synthesis in the CNCPS and DVE systems, whereas in INRA (2018), NorFor and NRC (2001), the contribution of an endogenous duodenal CP flow to the duodenal protein flow is also acknowledged. In the DVE systems, the metabolic faecal excretion is removed from the DiP, but for comparison purpose, it was not removed in the current comparison. Then, the microbial and the duodenal endogenous (when present) CP flows are converted to true protein flows, whereas undegraded dietary protein is assumed to be totally true protein. Finally, an intestinal digestibility coefficient is assigned to the different protein fractions. The estimations of dietary-undegraded $\mathrm{CP}$ and microbial $\mathrm{CP}$ rumen outflow are related to rate of degradation, rate of passage, protein rumen degradability and energy availability, each parameter being specifically characterised in each system. One major difference is that all systems but CNCPS rely on in sacco studies to estimate rumen degradability of $\mathrm{CP}$, whereas CNCPS has developed a system of CP fractions based on laboratory techniques. The true protein proportion of microbial CP is estimated at 0.80 and intestinal digestibility at 0.80 in all systems except DVE using 0.75 and 0.85 , and NorFor using 0.73 and 0.85 , respectively, for these parameters. The intestinal digestibility of the undegraded dietary protein mainly relies on the mobile bag technique. However, an in vitro procedure has been developed at Cornell and is now used to estimate intestinal protein digestibility for nonforage feeds (Ross et al., 2013; Gutierrez-Botero et al., 2014) although that data were not available for the comparison.

The distribution of the DiP supply between dietary undegraded, microbial and endogenous duodenal (when present) protein for the same 'example cow' for which exported proteins were estimated is also detailed in Table 2. Interestingly, the estimation of the microbial CP flow is relatively similar, except that of CNCPS, which is much higher than others. This might be specifically related to this diet, as this discrepancy between NRC (2001) and CNCPS has not been reported on a large number of diets (Pacheco et al., 2012). The starch content of the diet was, however, quite elevated and the CNCPS will predict significant growth of microbial protein when digestible starch is provided at that level if rumen $\mathrm{N}$ balance and the $\mathrm{pH}$ prediction do not modulate the yield. On the other hand, the prediction of the undegraded dietary protein is the lowest for NorFor.

Table 2 Distribution of the requirement and the supply of digestible protein (g/day) for one example cow ${ }^{1}$

\begin{tabular}{|c|c|c|c|c|c|c|c|c|c|c|}
\hline \multirow[b]{2}{*}{ Feeding system ${ }^{2}$} & \multicolumn{6}{|c|}{ Requirement } & \multicolumn{4}{|c|}{ Supply } \\
\hline & Total & Scurf & Endogenous urinary & Metabolic faecal & Milk protein & Duo endo ${ }^{4}$ & Total & Undegraded dietary & Microbial & Duo endo ${ }^{4}$ \\
\hline CNCPS & 2501 & 14 & 100 & 621 & 1766 & & 2573 & 1101 & 1472 & \\
\hline DVE-1991 3 & 2425 & 14 & 100 & 386 & 1925 & & 2238 & 1120 & 1118 & \\
\hline DVE- $2007^{3}$ & 2425 & 14 & 100 & 386 & 1925 & & 2273 & 1034 & 1239 & \\
\hline INRA (2018) & 2248 & 13 & 203 & 411 & 1621 & & 2290 & 1142 & 1148 & \\
\hline NorFor & 2172 & 14 & 100 & 337 & 1722 & & 2085 & 738 & 1258 & 89 \\
\hline NRC (2001) & 2639 & 14 & 100 & 583 & 1766 & 176 & 2427 & 1070 & 1248 & 109 \\
\hline
\end{tabular}

${ }^{1}$ Average cow of Study 1 producing $38.3 \mathrm{~kg}$ of milk at 3.09\% true protein, 3.27\% fat, eating $23 \mathrm{~kg} /$ day of dry matter of the $16.5 \%$ CP diet (Olmos Colmenero and Broderick, 2006), at 120 days in milk, not changing BW $(589 \mathrm{~kg})$ and not gestating.

${ }^{2}$ CNCPS = Cornell Net Carbohydrate and Protein System, v 6.5 (van Amburgh et al., 2015); DVE = Dutch protein evaluation system, DVE-1991 (Tamminga et al., 1994) and DVE-2007 (VanDuinkerken et al., 2011); INRA (2018); NRC (2001); NorFor (2011).

${ }^{3}$ In DVE, the metabolic faecal is not included in the requirement and is excluded from the supply, as it is considered to be a consequence of the diet and not the animal. For comparison purpose with the other feeding systems, this fraction has been added to the requirements and not removed from the supply in the current table.

${ }^{4}$ Duodenal endogenous flow. 


\section{Efficiency}

Once the exported proteins are estimated, an efficiency is assigned to each protein function. It is probably where the major differences reside between the different feeding systems in their ability to predict MPY responses to changes in dietary protein and/or energy supply. The efficiencies used in each system and according to the different protein functions are detailed in Table 3. Traditionally, feeding systems were using a fixed efficiency varying between 0.64 and 0.67 as still do the current American feeding systems as NRC (2001) and CNCPS (Van Amburgh et al., 2015). Note also that these two feeding systems have not assigned an efficiency to metabolic faecal protein, that is an efficiency of 1.0 has been assumed. In contrast, European feeding systems have adopted a variable efficiency for either all the exported proteins (excluding urinary endogenous; Sauvant et al., 2015; INRA, 2018) or have kept a fixed efficiency for the non-productive functions and a variable efficiency for the milk protein (NorFor, 2011; Van Duinkerken et al., 2011). For the INRA (2018), the single efficiency of utilisation of DiP assigned to all the exported proteins is not used to predict MPY but is rather derived 'a posteriori', as described below. The efficiency is then calculated as the sum of the exported proteins divided by DiP supply. Note that endogenous urinary secretion is excluded from all these parameters in INRA (2018), with an efficiency of 1 assigned to it.

\section{Prediction of milk protein yield}

For all the models, except INRA (2018), MPY is calculated as follows:

MPY $=($ DiP available for milk $) \times($ efficiency for milk protein $)$ where DiP available for milk = DiP supply - DiP required for non-productive functions, DiP required for non-productive functions being the sum of each exported protein divided by its respective efficiency. The exported proteins for nonproductive functions are calculated as indicated in Table 1 and the efficiency of utilisation of DiP, fixed or variable, as indicated in Table 3.

As mentioned above, in INRA (2018), the sum of exported proteins (including MPY but excluding endogenous urinary excretion) is first estimated, using an equation including available DiP (excluding endogenous urinary excretion), theoretical net energy of lactation and DiP balances (using a reference situation as nutritional pivot, i.e. the potential of the animal). The MPY is then calculated using the total predicted exported proteins minus the estimations for nonproductive functions.

\section{Amino acid requirements}

Only CNCPS uses a factorial approach to determine the AA requirement of all $E A A$, giving the requirement in $g$ of $A A$ / day. For the example cow, the $A A$ requirements averaged 60 , $128,242,181,64,134,98,38$ and $142 \mathrm{~g} /$ day of His, Ile, Leu, Lys, Met, Phe, Thr, Trp and Val, respectively. The other feeding systems are using a proportional approach where the requirement is the supply of the $A A$ expressed as a percentage of DiP supply: NRC has recommendations for Lys and Met, whereas NorFor and INRA (2018) also include His in addition to Lys and Met. Feeding systems using the proportional approach have recommendations in the same range for Lys and Met. Institut National de la Recherche Agronomique (2018) proposed an ideal profile of EAA (as \% of DiP): Arg (3.4), His (2.4), Ile ( $\geqslant 5.0)$, Leu (8.5), Lys (7.0), Met (2.4), Phe (4.4-5.0), Thr ( $\geqslant 3.8)$ and Val (4.9-5.7). Recommendations for His, Lys and Met are, respectively, 2.2\%,6.6\% and $2.2 \%$ of DiP in NorFor. The NRC (2001) initial recommendations of $7.2 \%$ and $2.4 \%$ have been revisited with an expanded database and the recommendations slightly decreased to $6.89 \%$ and $2.23 \%$ of DiP to optimise MPY and

Table 3 Efficiency of utilisation of the digestible protein used by different protein feeding systems for dairy cows

\begin{tabular}{|c|c|c|c|c|c|}
\hline \multirow[b]{2}{*}{$\begin{array}{l}\text { Feeding } \\
\text { system }^{1}\end{array}$} & \multicolumn{5}{|c|}{ Protein function } \\
\hline & Scurf & $\begin{array}{c}\text { Endogenous } \\
\text { urinary }\end{array}$ & Metabolic faecal & $\begin{array}{l}\text { Endogenous } \\
\text { duodenal }\end{array}$ & Milk protein ${ }^{2}$ \\
\hline CNCPS v6.5 & 0.67 & 0.67 & 1 & - & 0.67 \\
\hline DVE & 0.67 & 0.67 & 0.67 & - & $\begin{array}{l}117.6-3.044 \times \mathrm{DiP} / \mathrm{NEL}_{\mathrm{g} / \mathrm{MJ}-} \\
0.23 \times \mathrm{FPCM}_{\mathrm{kg} / \mathrm{day}}\end{array}$ \\
\hline INRA (2018) & As milk & 1 & As milk & - & $\begin{array}{l}67.0 \times \exp [-0.007 \times \\
\left(\mathrm{DiP}_{\mathrm{g} / \mathrm{kgDM}}-100\right)^{3}\end{array}$ \\
\hline NorFor & 0.67 & 0.67 & $\begin{array}{l}0.67 \text { for the forestomach/ } \\
1.0 \text { for the small intestine }\end{array}$ & - & $\begin{array}{l}189.4-11.14 \times\left(\mathrm{DiP}_{\text {Milk }} / \mathrm{NEL}_{\text {Milk }}\right) \\
\quad+0.215 \times\left(\mathrm{DiP}_{\text {Milk }} / \mathrm{NEL}_{\text {Milk }}\right)\end{array}$ \\
\hline NRC (2001) & 0.67 & 0.67 & 1 & 0.67 & 0.67 \\
\hline
\end{tabular}

${ }^{1}$ CNCPS = Cornell Net Carbohydrate and Protein System, v 6.5 (van Amburgh et al., 2015); DVE = Dutch protein evaluation system; includes both DVE-1991 (Tamminga et al., 1994) and DVE-2007 (VanDuinkerken et al., 2011); INRA (2018); NRC (2001); NorFor (2011).

${ }^{2}$ Units are given in subscripts; DiP = digestible protein supply; NEL = net energy of lactation; FPCM = fat- and protein-corrected milk; DiP Mikk $/ \mathrm{NEL}_{\text {Milk }}=\mathrm{DiP}_{\text {and NEL left }}$ for milk in $\mathrm{g} / \mathrm{MJ}$.

${ }^{3}$ This equation is only used as a proxy: the efficiency is calculated a posteriori as the ratio of $\Sigma$ (Exported proteins + protein accretion)/(DiP-endogenous urinary), where scurf and metabolic faecal export protein are calculated as defined in Table 1 and milk protein yield is estimated based on DiP and energy supply, and the potential of the cow. 
$6.95 \%$ and $2.38 \%$ of DiP to optimise milk protein concentration (Whitehouse et al., 2010a and 2010b). These authors also demonstrated that these proportions change depending of the feeding system used and should therefore be evaluated within each feeding system. Interestingly, when calculated as part of the DiP requirement, CNCPS factorial recommendations averaged $2.3 \%, 7.0 \%$ and $2.5 \%$ of DiP for His, Lys and Met, respectively.

\section{Description of the diets from the selected studies}

To compare the responsiveness of the feeding systems to dietary changes, two situations were selected: the first involves variation of protein supply whereas the second includes variations in protein and/or energy supply. In order to compare predictions with observed responses, one publication reporting each situation was selected. The selection was based on the report of diet composition (feed ingredients, dietary chemical composition) and cows' characteristics (BW, days in milk) with MPY reported for each individual treatment. The study of Olmos Colmenero and Broderick (2006) reporting the effect of protein supply, with five levels of CP concentration, from $13.5 \%$ to $19.4 \%$ of DM, will be referred to as Study 1 . Cows in this study averaged $589 \mathrm{~kg} \mathrm{BW}, 120$ days in milk and were multiparous. For the interaction protein $\times$ energy, a study with a $2 \times 2$ factorial arrangement of protein and energy supply was selected (Rius et al., 2010) and will be referred to as Study 2. Cows in this study averaged $630 \mathrm{~kg} \mathrm{BW}, 185$ days in milk and were multiparous. Diet and feed ingredient compositions are

Table 4 Experimental diets of the selected study comparing grading dietary CP supply in lactating dairy cows

\begin{tabular}{lrrrrr}
\hline \hline & \multicolumn{5}{c}{ Dietary CP (\% of DM) } \\
\cline { 2 - 7 } Ingredient (\% DM) & 13.5 & 15 & 16.5 & 17.9 & 19.4 \\
\hline Alfalfa silage & 25 & 25 & 25 & 25 & 25 \\
Corn silage & 25 & 25 & 25 & 25 & 25 \\
Rolled high-moisture corn & 44.0 & 40.6 & 37.2 & 33.8 & 30.4 \\
Solvent extracted soya bean meal & 2.4 & 5.8 & 9.2 & 12.6 & 16 \\
Roasted soya beans & 2.5 & 2.5 & 2.5 & 2.5 & 2.5 \\
Vitamin-mineral premix & 1.1 & 1.1 & 1.1 & 1.1 & 1.1 \\
\hline \hline
\end{tabular}

$\mathrm{DM}=$ dry matter. detailed in Tables 4 to 7. These detailed descriptions will allow nutritionists wanting to test different models to have on hand all the needed information to make their own comparison.

\section{Comparison of observed $v$. predicted milk protein yields}

Study 1: variable dietary $C P$ supply

Estimated DiP supply with the different feeding systems is detailed in Table 8. The same trends as those observed for the example cow are observed, that is lowest estimation for NorFor and highest estimation for CNCPS v6.5.5. However, the variation between the $13.5 \% \mathrm{CP}$ and $19.4 \% \mathrm{CP}$ were larger for NorFor (718 g/day) than for CNCPS (441 g/day). There is no measurement that can be done to directly assess the true flow of DiP (Lapierre et al., 2006); hence, it is not possible to directly assess the accuracy and the precision of these measurements. However, these predictions are used in conjunction with estimated exported proteins and efficiency to predict MPY.

The observed dry matter intake (DMI), MPY and $\mathrm{N}$ balance and predicted MPY for Study 1 are presented in Table 8 as well as the efficiency used to predict MPY at the different DiP supplies for the various feeding systems. At low protein

Table 6 Experimental diets of the selected study testing protein and energy supply in lactating dairy cows

\begin{tabular}{|c|c|c|c|c|}
\hline \multirow[b]{2}{*}{ Ingredients (\% DM) } & \multicolumn{4}{|c|}{ Experimental diets } \\
\hline & HE/HP & HE/LP & LE/HP & LE/LP \\
\hline Corn silage & 34.97 & 34.89 & 45.91 & 45.92 \\
\hline Mixed timothy and clover silage & 4.81 & 4.80 & 4.80 & 4.80 \\
\hline Cottonseed hulls & 0 & 0 & 20.53 & 17.89 \\
\hline Soya bean hulls & 25.8 & 31.62 & 10.70 & 19.65 \\
\hline Corn grain, ground and dry & 22.17 & 22.13 & 0 & 0 \\
\hline Tallow & 0 & 1.19 & 0 & 1.13 \\
\hline Urea & 1.16 & 1.24 & 0.74 & 0.79 \\
\hline Soya bean meal, solvent extracted & 3.16 & 2.64 & 9.37 & 8.35 \\
\hline Protected soya bean meal ${ }^{1}$ & 6.66 & 0 & 6.57 & 0 \\
\hline Mineral-vitamin premix & 1.27 & 1.49 & 1.38 & 1.47 \\
\hline
\end{tabular}

$\mathrm{DM}=$ dry matter; $\mathrm{HE} / \mathrm{HP}=$ high energy/high protein; $\mathrm{HE} / \mathrm{LP}=$ high energy/low protein; LE/HP = low energy/high protein; LE/LP = low energy, low protein. ${ }^{1}$ Mechanical expeller process.

Table 5 Composition of feed ingredients of the selected study comparing grading dietary CP supply in lactating dairy cows

\begin{tabular}{lccccc}
\hline \hline & & & & Rolled high & \multicolumn{2}{c}{ Solvent-extracted } & Roasted \\
\cline { 4 - 6 } Items (\% DM) & Alfalfa silage & Corn silage & Moisture corn & Soya bean meal & Soya beans \\
\hline CP & 22.9 & 7.23 & 8.44 & 52.0 & 40.0 \\
NDF & 35.8 & 36.1 & 8.32 & 8.06 & 23.9 \\
ADF & 27.0 & 18.3 & 1.97 & 4.57 & 4.04 \\
Neutral detergent indigestible CP & 1.41 & 0.28 & 0.18 & 0.26 & 3.30 \\
Ash & 10.70 & 4.13 & 1.95 & 5.40 \\
\hline \hline
\end{tabular}

$\mathrm{DM}=$ dry matter. 
Table 7 Composition of feed ingredients of the selected study testing protein and energy supply in lactating dairy cows

\begin{tabular}{|c|c|c|c|c|c|c|c|}
\hline Items (\% DM) & $\begin{array}{l}\text { Corn } \\
\text { silage }^{1}\end{array}$ & $\begin{array}{l}\text { Mixed timothy and } \\
\text { clover silage }^{1}\end{array}$ & $\begin{array}{l}\text { Cottonseed } \\
\text { hulls }^{2}\end{array}$ & $\begin{array}{l}\text { Soya bean } \\
\text { hulls }^{2}\end{array}$ & $\begin{array}{l}\text { Corn } \\
\text { grain }^{2}\end{array}$ & $\begin{array}{c}\text { Soya bean meal, solvent } \\
\text { extracted }^{2}\end{array}$ & $\begin{array}{l}\text { Protected soya } \\
\text { bean meal }\end{array}$ \\
\hline $\mathrm{CP}$ & 8.9 & 17.6 & 7.0 & 13.9 & 10.5 & 55.0 & 55.0 \\
\hline NDF & 43.7 & 48.8 & 80.0 & 65.0 & 9.5 & 9.8 & 21.7 \\
\hline ADF & 26.3 & 38.0 & 62.0 & 47.0 & 3.4 & 6.2 & 10.4 \\
\hline Lignin & 3.0 & 7.4 & 15.0 & 5.0 & 0.9 & 0.5 & 1.5 \\
\hline $\begin{array}{l}\text { Neutral detergent } \\
\text { indigestible CP }\end{array}$ & & & 3 & 3.5 & 0.7 & 0.7 & 9.6 \\
\hline Fat & 3.6 & 2.5 & & & & & \\
\hline
\end{tabular}

$\mathrm{DM}=$ dry matter.

${ }^{1}$ As reported.

${ }^{2}$ As used in the comparison; selected to fit the best the reported composition of the concentrate.

Table 8 Observed dry matter (DM) intake, milk protein yield and $N$ balance and estimations of the digestible protein flows, predicted milk protein yield (MPY), and the efficiency of lactation used by different feeding systems for the selected study comparing grading dietary CP supply in lactating dairy cows ${ }^{1}$

\begin{tabular}{|c|c|c|c|c|c|c|}
\hline & \multirow[b]{2}{*}{ Feeding system ${ }^{2}$} & \multicolumn{5}{|c|}{ Dietary CP $(\%$ of DM) } \\
\hline & & 13.5 & 15.0 & 16.5 & 17.9 & 19.4 \\
\hline Observed DM intake (kg/day) & & 22.3 & 22.2 & 23 & 22.3 & 22.9 \\
\hline Observed milk protein yield (g/day) ${ }^{3}$ & & 1110 & 1115 & 1180 & 1130 & 1150 \\
\hline Observed $($ MPY + corrected N balance $\times 6.25)(\mathrm{g} / \text { day })^{4}$ & & 1113 & 1218 & 1309 & 1289 & 1338 \\
\hline \multirow[t]{6}{*}{ Estimated digestible protein flow (g/day) } & CNCPS & 2307 & 2386 & 2573 & 2542 & 2748 \\
\hline & DVE- $1991^{5}$ & 1845 & 1998 & 2238 & 2333 & 2562 \\
\hline & DVE- $2007^{5}$ & 1926 & 2056 & 2273 & 2342 & 2548 \\
\hline & INRA (2018) & 1951 & 2071 & 2290 & 2345 & 2552 \\
\hline & NorFor & 1677 & 1830 & 2085 & 2159 & 2395 \\
\hline & NRC (2001) & 2002 & 2215 & 2427 & 2478 & 2675 \\
\hline \multirow[t]{6}{*}{ Predicted milk protein yield (g/day) } & CNCPS & 1112 & 1167 & 1278 & 1256 & 1398 \\
\hline & DVE-1991 & 1083 & 1160 & 1279 & 1298 & 1386 \\
\hline & DVE-2007 & 1126 & 1186 & 1293 & 1301 & 1382 \\
\hline & INRA (2018) & 1053 & 1097 & 1141 & 1201 & 1222 \\
\hline & NorFor & 1147 & 1173 & 1246 & 1210 & 1256 \\
\hline & NRC (2001) & 805 & 957 & 1082 & 1132 & 1251 \\
\hline \multirow[t]{6}{*}{ Efficiency of lactation } & CNCPS & 0.67 & 0.67 & 0.67 & 0.67 & 0.67 \\
\hline & DVE-1991 & 0.80 & 0.77 & 0.74 & 0.71 & 0.67 \\
\hline & DVE-2007 & 0.79 & 0.76 & 0.73 & 0.70 & 0.67 \\
\hline & INRA (2018) & 0.84 & 0.79 & 0.73 & 0.69 & 0.63 \\
\hline & NorFor & 0.94 & 0.86 & 0.78 & 0.72 & 0.66 \\
\hline & NRC (2001) & 0.67 & 0.67 & 0.67 & 0.67 & 0.67 \\
\hline
\end{tabular}

${ }^{1}$ Olmos Colmenero and Broderick (2006).

${ }^{2}$ CNCPS = Cornell Net Carbohydrate and Protein System, v 6.5 .5 (van Amburgh et al., 2015); DVE/OEB= Dutch protein evaluation system, DEV-1991 (Tamminga et al., 1994) and DEV-2007 (VanDuinkerken et al., 2011); INRA (2018); NRC (2001); NorFor (2011).

${ }^{3} \mathrm{SEM}=30 \mathrm{~g}$ protein/day; quadratic effect of CP level, $P=0.09$.

${ }^{4} \mathrm{~N}$ retention was corrected according to Spanghero and Kowalski (1997) who reported that usually N balances are over-estimated by $53 \%$.

${ }^{5}$ Including metabolic faecal protein flow.

supply, MPY was severely under-predicted by NRC (2001). The fixed efficiency used by NRC (2001) is partly responsible for the under-prediction at low DiP supply. Interestingly, the European feeding systems deal well with a low protein supply, with roughly adequate predictions of MPY at low protein supply. The three European systems are using a variable efficiency which includes protein supply and energy: the estimated efficiency varied between 0.79 and 0.94 at the low supply. The CNCPS which is using a fixed efficiency at 0.67 was fine with the predicted MPY at low supply but highly over-predicted MPY at the high supply. In fact, all feeding systems over-predicted MPY at the highest DiP supply, but NRC, NorFor and INRA (2018) to a lesser extent. Overall, the feeding systems using a fixed efficiency have a 
strong slope bias in their estimation of MPY when DiP supply varies. The systems using a variable efficiency of utilisation of DiP including DiP and energy supply, especially INRA (2018) and NorFor, responded the best to variation in DiP supply. The efficiency of utilisation of DiP changes substantially in NorFor, varying from 0.94 at the low CP supply and down to 0.66 at the high supply: these fairly large variations accommodated well the estimated supply to yield reasonable predicted MPY in all cases. The lower range of variation of efficiency in INRA compared to NorFor is logical because calculation of efficiency is only applied to milk protein for NorFor whereas it applies to the sum of scurf, metabolic faecal loss and MPY in INRA (2018).

The observed $\mathrm{N}$ retention was corrected according to Spanghero and Kowalski (1997) who reported that usually $\mathrm{N}$ balances are over-estimated by $53 \%$. Therefore, the observed exported protein was calculated as the sum of observed MPY plus [observed $N$ balance $x$ $(1-0.53) \times 6.25$ ] and compared to the predicted MPY, accounted for the difference between total exported proteins and those for non-productive functions. Within each model, the same trends were observed as when only predicted MPY was used, but with an under-prediction of the exported protein for most of the treatments. This raises two issues. First, the well-known over-prediction of measured $\mathrm{N}$ balance as described above, although corrected, might still be present and inflate the observed exported protein. Second, because it is not a precise and easy measurement, especially on short-term studies, $\mathrm{N}$ balance is often not measured. Nevertheless, ignoring the potential $\mathrm{N}$ accretion related to positive $\mathrm{N}$ balance might contribute to the apparent decreased efficiency of $\mathrm{N}$ utilisation observed at high protein supply.

\section{Study 2: protein $x$ energy interaction}

Estimated DiP supply with the different feeding systems is detailed in Table 9. Decreasing energy supply had limited effect on estimated DiP supply at high protein level, but substantially decreased it at low protein supply, the difference originating both from microbial and undegraded dietary protein. Therefore, the reduction of observed MPY when energy supply decreased would be more related to a decreased efficiency when protein supply is high but would be partially related to both a reduced DiP supply and a reduced efficiency when protein supply is low. The observed DMI and MPY, predicted MPY and the efficiency used to predict MPY with the different feeding systems are presented in Table 9. Unfortunately, predictions made with the DVE feeding systems could not be kept in: too many feed ingredients were not well characterised in the DVE systems which were then yielding unreliable predictions. The over-prediction of MPY observed with the high-protein diet observed using NRC (2001) in Study 1 is also observed within this study, with over-prediction being exacerbated at low energy supply: this could be related to the fixed efficiency but also to the high prediction of DiP supply at low energy/high protein with this feeding system. The European systems behave well at the high energy/high protein supply, the predictions being in the range of observed +1 SEM. At the low-energy/high-protein diet, NorFor provided the best prediction, with an overestimation of $77 \mathrm{v} .154 \mathrm{~g}$ for INRA (2018), $160 \mathrm{~g}$ for CNCPS and $500 \mathrm{~g}$ for NRC. NorFor was more reactive to alter the estimation of the efficiency with the variation of energy supply, the efficiency decreasing by 0.1 unit at low energy supply.

It has to be remembered that the digestibility and rates of digestion of the forages was unknown for this evaluation; therefore, the sensitivity to these predictions is contingent on

Table 9 Observed dry matter (DM) intake and milk protein yield and estimations of the digestible protein flows, predicted milk protein yield, and the efficiency of lactation used by different feeding systems for the selected study testing protein and energy interaction in lactating dairy cows ${ }^{1}$

\begin{tabular}{|c|c|c|c|c|c|}
\hline & \multirow[b]{2}{*}{ Feeding system ${ }^{2}$} & \multicolumn{4}{|c|}{ Experimental diets } \\
\hline & & $\mathrm{HE} / \mathrm{HP}$ & HE/LP & LE/HP & LE/LP \\
\hline Observed DM intake (kg/day) & & 24.8 & 24.4 & 24.9 & 23.2 \\
\hline Observed milk protein yield $(\mathrm{kg} / \mathrm{day})^{3}$ & & 1130 & 1030 & 910 & 870 \\
\hline \multirow[t]{4}{*}{ Estimated digestible protein flow (g/day) } & CNCPS & 2579 & 2212 & 2568 & 2076 \\
\hline & INRA (2018) & 2669 & 2103 & 2601 & 1931 \\
\hline & NorFor & 2789 & 2351 & 2780 & 2203 \\
\hline & NRC (2001) & 2927 & 2335 & 2979 & 2228 \\
\hline \multirow[t]{4}{*}{ Predicted milk protein yield (g/day) } & CNCPS & 1136 & 876 & 1070 & 760 \\
\hline & INRA (2018) & 1184 & 1079 & 1064 & 883 \\
\hline & NorFor & 1175 & 1132 & 987 & 863 \\
\hline & NRC (2001) & 1379 & 990 & 1409 & 941 \\
\hline \multirow[t]{4}{*}{ Efficiency of lactation } & CNCPS & 0.67 & 0.67 & 0.67 & 0.67 \\
\hline & INRA (2018) & 0.65 & 0.79 & 0.61 & 0.71 \\
\hline & NorFor & 0.54 & 0.65 & 0.46 & 0.54 \\
\hline & NRC & 0.67 & 0.67 & 0.67 & 0.67 \\
\hline
\end{tabular}

$\mathrm{HE} / \mathrm{HP}=$ high energy/high protein; HE/LP = high energy/low protein; LE/HP = low energy/high protein; LE/LP = low energy, low protein.

${ }^{1}$ Rius et al. (2010).

${ }^{2}$ CNCPS = Cornell Net Carbohydrate and Protein System, v 6.5 .5 (van Amburgh et al., 2015); NRC (2001); NorFor (2011); INRA (2018).

${ }^{3} \mathrm{SEM}=50 \mathrm{~g}$ protein/day: energy effect, $P=0.001$; protein effect, $P=0.16$; energy $\times$ protein interaction, $P=0.57$. 
having adequate information to describe the forage and feed chemistry and ruminal digestion. However, when all the nine responses are pooled and regressed on the observed values only NorFor and INRA (2018) presented a regression not different from $Y=X$ with respective values of RMSE of 31 and $65 \mathrm{~g}$. For the other systems the slope was different from 1 and values of RMSE are of 117 , and $119 \mathrm{~g}$ for NRC (2001) and CNCPS, respectively.

\section{Opportunities and challenges}

The expression of the recommendations of EAA as a proportion of the EAA relative to DiP should be used with caution, as it can be misleading. Indeed, for example, Lys supply, as \% of DiP, was not altered between the $13.5 \%$ CP and $19.4 \% \mathrm{CP}$ diets, varying from 6.63 to $6.69,6.53$ to 6.51 and 6.60 to 6.07 for NorFor, DVE and INRA (2018), respectively; the supply of Met, as \% of DiP even decreased from 2.29 to $2.10,2.36$ to 2.09 and 1.93 to 1.77 , respectively, for the same feeding systems. Therefore, a correct acknowledgement of the $A A$ requirement cannot be based solely on a proportion of DiP, but it can be used as a tool to improve the prediction of MPY to dietary changes. Indeed, for example, INRA (2018) uses the percentage of Lys and Met relative to DiP to modulate the response of MPY and milk protein concentration. On a long-term basis, we should target expressing the AA requirement as a digestible flow (g/day): this approach requires, in addition of the determination of export protein, the AA composition of these protein and associated efficiency of utilisation. More work is needed to insure that increased complexity in the system results in gaining precision of MPY prediction. However, in the context where the efficiency of utilisation of individual AA will also be altered by energy supply, expression of requirements of individual AA will also need to be given in relation to energy supply.

\section{Conclusion}

Although the comparison was limited only to two reported studies, it clearly indicates that inclusion of a variable efficiency of utilisation of DiP is crucial to improve the prediction of MPY. Both systems using a variable efficiency account for DiP and energy supply. However, NorFor assigns the variable efficiency only to MPY whereas INRA (2018) applies the variable efficiency to all protein requirements (excluding endogenous urinary). In addition, in NorFor, efficiency only depends on available DiP and energy for milk whereas in INRA (2018), the estimation of MPY and subsequent efficiency is based on DiP and energy theoretical balances compared to a nutritional pivot situation. A thorough comparison of the more simple and more complex approaches in a wide range of applications will be needed to estimate if inclusion of factors other than protein and energy supply truly improves the prediction of MPY.

\section{Acknowledgements}

The authors are grateful to the following persons for their contribution to the current comparison of feeding systems: Nicolaj I. Nielsen (SEGES \& NorFor amba, Denmark), Patrick Chapoutot and Pierre Nozière (INRA, France) and Simon Binggeli (Université Laval, QC, Canada). The contribution of M. Larsen was supported by the Danish Milk Levy Fund.

\section{Declaration of interest \\ None}

\section{Ethics statement \\ None}

\section{Software and data repository resources \\ None}

\section{References}

Centraal Veevoederbureau (CVB) 2016. CVB feed table 2016: chemical composition and nutritional values of feedstuffs. Federatie Nederlandse Diervoederketen and Wageningen Livestock Research, The Netherlands.

Daniel JB, Friggens NC, Chapoutot P, Van Laar H and Sauvant D 2016. Milk yield and milk composition responses to change in predicted net energy and metabolizable protein: a meta-analysis. Animal 10, 1975-1985.

Daniel JB, Friggens NC, Van Laar H, Ferris CP and Sauvant D 2017. A method to estimate cow potential and subsequent responses to energy and protein supply according to stage of lactation. Journal of Dairy Science 100 , 3641-3657.

Dijkstra J, France J, Ellis JL, Strathe AB, Kebreab E and Bannink A 2013 a. Production efficiency in ruminants: feed, nitrogen and methane. In Sustainable animal agriculture (ed. E Kebreab), pp. 10-25. CAB International, Wallingford, UK.

Dijkstra J, Reynolds CK, Kebreab E, Bannink A, Ellis JL, France J and Van Vuuren AM 2013b. Challenges in ruminant nutrition: towards minimal nitrogen losses in cattle. In Energy and protein metabolism and nutrition in sustainable animal production. EAAP No. 134, p. 535.

Fox DG, Sniffen CJ, O'Connor JD, Russell JB and Van Soest PJ 1992. A net carbohydrate and protein system for evaluating cattle diets: III. Cattle requirements and diet adequacy. Journal of Animal Science 70, 3578-3596.

Fox DG, Tedeschi LO, Tylutki TP, Russell JB, Van Amburgh ME, Chase LE, Pell AN and Overton TR 2004. The Cornell Net Carbohydrate and Protein System model for evaluating herd nutrition and nutrient excretion. Animal Feed Science and Technology 112, 29-78.

Gutierrez-Botero M, Foskolos A, Ross DA and Van Amburgh ME. 2014. Balancing for intestinal nitrogen digestibility in high producing lactating cattle: one step closer to feeding a cow like a pig?. In Cornell Nutrition Conference for Feed Manufacturers, Department of Animal Science, Cornell University, 21-23 October 2014, Syracuce, NY, USA, pp. 140-147.

Huhtanen P and Hristov AN 2009. A meta-analysis of the effects of dietary protein concentration and degradability on milk protein yield and milk $\mathrm{n}$ efficiency in dairy cows. Journal of Dairy Science 92, 3222-3232.

Institut National de la Recherche Agronomique (INRA) 2007. Alimentation des bovins, ovins et caprins - besoins des animaux - valeurs des aliments - Tables INRA 2007. INRA, Versailles, France.

Institut National de la Recherche Agronomique (INRA) 2018. INRA feeding system for ruminants. Wageningen Academic Publishers, Wageningen, The Netherlands. 640 pp.

Lapierre $H$, Pacheco D, Berthiaume R, Ouellet DR, Schwab CG, Dubreuil P, Holtrop $G$ and Lobley GE 2006. What is the true supply of amino acids for a dairy cow? Journal of Dairy Science 89 (suppl. 1), E1-E14.

National Research Council (NRC) 2001. Nutrient requirements of dairy cattle, 7th revised edition. National Academy of Sciences., Washington, DC, USA. 
NorFor 2011. The Nordic feed evaluation system. Wageningen Academic Publishers, The Netherlands.

O'Connor JD, Sniffen CJ, Fox DG and Chalupa W 1993. A net carbohydrate and protein system for evaluating cattle diets: IV. Predicting amino acid adequacy. Journal of Animal Science 71, 1298-1311.

Olmos Colmenero JJ and Broderick GA 2006. Effect of dietary crude protein concentration on ruminal nitrogen metabolism in lactating dairy cows. Journal of Dairy Science 89, 1694-1703.

Pacheco D, Patton RA, Parys C and Lapierre H 2012. Ability of commercially available dairy ration programs to predict duodenal flows of protein and essential amino acids in dairy cows. Journal of Dairy Science 95, 937-963.

Rius AG, McGilliard ML, Umberger CA and Hanigan MD 2010. Interactions of energy and predicted metabolizable protein in determining nitrogen efficiency in the lactating dairy cow. Journal of Dairy Science 93, 2034-2043.

Ross DA, Gutierrez-Botero M and Van Amburgh ME. 2013. Development of an in vitro assay to evaluate intestinal protein digestibility in ruminants. In Cornell Nutrition Conference for Feed Manufacturers, Department of Animal Science, Cornell University, Syracuce, NY, USA, pp. 190-202.

Russell JB, O'Connor JD, Fox DG, Van Soest PJ and Sniffen CJ 1992. A net carbohydrate and protein system for evaluating cattle diets: I. Ruminal fermentation. Journal of Animal Science 70, 3551-3561.

Sauvant $D$ and Nozière $P$ 2016. Quantification of the main digestive processes in ruminants: the equations involved in the renewed energy and protein feed evaluation systems. Animal 10, 755-770.

Sauvant D, Cantalapiedra-Hijar G, Delaby L, Daniel JB, Faverdin P and Noziere P 2015. Actualisation des besoins protéiques des ruminants et détermination des réponses des femelles laitières aux apports de protéines digestibles dans l'intestin. INRA Productions Animales 28, 347-368.

Sniffen CJ, O'Connor JD, Van Soest PJ, Fox DG and Russell JB 1992. A net carbohydrate and protein system for evaluating cattle diets: II. Carbohydrate and protein availability. Journal of Animal Science 70, 3562-3577.

Spanghero M and Kowalski ZM 1997. Critical analysis of N balance experiments with lactating cows. Livestock Production Science 52, 113-122.
Swanson EW 1977. Factors for computing requirements of protein for maintenance of cattle. Journal of Dairy Science 60, 1583-1593.

Tamminga S, Brandsma GG, Dijkstra J, Van Duinkerken G, Van Vuuren AM and Blok MC 2007. Protein evaluation for ruminants: the DVE/OEB 2007 system. CVB Documentation report nr. 53. Centraal Veevoederbureau, Lelystad, The Netherlands.

Tamminga S, Van Straalen WM, Subnel APJ, Meijer RGM, Steg A, Wever CJG and Blok MC 1994. The Dutch protein evaluation system: the DVE/OEB-system. Livestock Production Science 40, 139-155.

Tylutki TP, Fox DG, Durbal VM, Tedeschi LO, Russell JB, Van Amburgh ME, Overton TR, Chase LE and Pell AN 2008. Cornell Net Carbohydrate and Protein System: a model for precision feeding of dairy cattle. Animal Feed Science and Technology 143, 174-202.

Van Amburgh ME, Collao-Saenz EA, Higgs RJ, Ross DA, Recktenwald EB, Raffrenato E, Chase LE, Overton TR, Mills JK and Foskolos A 2015. The Cornell Net Carbohydrate and Protein System: updates to the model and evaluation of version 6.5. Journal of Dairy Science 98, 6361-6380.

Van Duinkerken G 2011. Nitrogen efficiency of dairy cattle: from protein evaluation to ammonia emission. PhD thesis, Wageningen University, Wageningen, The Netherlands.

Van Duinkerken G, Blok MC, Bannink A, Cone JW, Dijkstra J, Van Vuuren AM and Tamminga S 2011. Update of the Dutch protein evaluation system for ruminants: the DVE/OEB2010 system. Journal of Agricultural Science 149, 351-367.

Whitehouse N, Schwab C, Luchini D and Sloan B 2010a. A critique of doseresponse plots that relate changes in content and yield of milk protein to predicted concentrations of lysine in metabolizable protein by the NRC (2001), CPM-Dairy (v.3.0.10) and AMTS.Cattle (v.2.1.1) models. Journal of Dairy Science 93 (E-suppl. 1), 447

Whitehouse N, Schwab C, Luchini D and Sloan B 2010b. A critique of doseresponse plots that relate changes in content and yield of milk protein to predicted concentrations of methionine in metabolizable protein by the NRC (2001), CPM-Dairy (v.3.0.10) and AMTS.Cattle (v.2.1.1) models. Journal of Dairy Science 93 (E-suppl. 1), 447. 